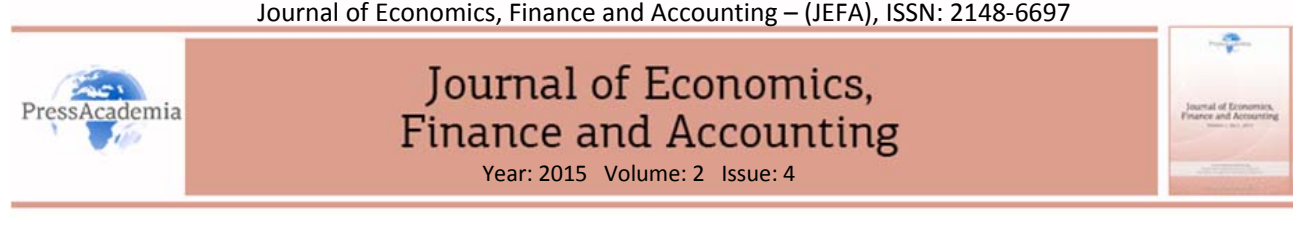

\title{
TOPSIS PERFORMANCE EVALUATION MEASURES AND RELATION BETWEEN FINANCIAL RATIOS AND STOCK RETURNS ${ }^{1}$
}

\section{DOI: 10.17261/Pressacademia.2015414363}

\author{
Ercan Ozen', Eser Yesildag' ${ }^{2}$, Mustafa Soba ${ }^{3}$ \\ 'Uşak University. eozentr@hotmail.com \\ Uşak University. eseryesildag@gmail.com \\ ${ }^{3}$ Uşak University. Mustafa.soba@usak.edu.tr
}

\section{Keywords}

Financial ratios, Borsa

Istanbul, return on

stock, TOPSIS, financial

performance

JEL Classification

G11, G32, L00

\section{ABSTRACT}

The purpose of this study is to find out the financial performances of the companies by using TOPSIS, one of the mostly used multi-criteria decision-making methods, and also to measure the relationship between stock returns and the financial performances with financial ratios. For this reason, selected 4 companies trading at Borsa İstanbul Food Index and their 20 financial ratios between 2000:4 and 2014:3 are used in the study. Finally the relations are investigated by Correlation Analysis. According to analysis, there is no relationship between TOPSIS financial performance scores and return on stocks. When we look at the relationship between financial ratios and return on stocks, there is no significant relationship among variables in 3 out of 4 companies. However, there is a significant positive statistical relationship with only one company. Research results show that stock prices are determined by external factors rather than internal factors in small companies.

\section{TOPSIS PERFORMANS DEĞERLEME ÖLÇÜSÜ VE FINANSAL ORANLAR İLE HISSE SENEDI GETIRi iLIŞKISi}

\section{Anahtar Kelimeler \\ Finansal oranlar, Borsa İstanbul, hisse senedi getirisi, TOPSIS, finansal performans}

JEL Sınıflandırması G11, G32, L00

\section{ÖZET}

Bu çalışmanın amacı, çok kriterli karar verme yöntemlerinden biri olan TOPSIS yöntemiyle şirketlerin finansal performanslarını belirlemek, ayrıca bu performans ve finansal oranlarla hisse senetlerinin borsa getirileri arasındaki ilişkiyi ölçmektir. Bu nedenle çalışmada, Borsa İstanbul Gıda Endeksinde yer alan seçilmiş dört işletme ve bu işletmelerin 2000:4-2014:3 dönemlerine ait yirmi finansal oran kullanılmış, ilişkiler korelasyon analizi yardımıyla araştııılmıştır.Korelasyon analizine göre, TOPSIS performans skorları ile hisse senedi getirileri arasında bir ilişki bulunmamıştır. Finansal oranlar ile hisse senedi getirileri arasındaki ilişkiye bakıldığında, dört işletmenin üçünde değişkenler arasında genel olarak bir ilişki bulunmamıştır. Sadece bir işletmenin kârlılık oranları ile piyasa getirileri arasında istatistiksel olarak anlamlı pozitif ilişkiler bulunmuştur. Çalışma sonuçları hisse senedi fiyatlarının özellikle küçük işletmelerde daha çok dışsal faktörlerce belirlendiğini ortaya çıkarmıştır. 


\section{GíRiş}

Yatırımcılar, sahip oldukları tasarruflarla gelirlerini ve servetlerini arttırmayı amaçlamaktadır. Hisse senetleri, bu amaca hizmet edecek finansal yatırımlardan birisini oluşturmaktadır. İstenen getirilerin elde edilmesi için hisse senetlerinin iyi analiz edilerek en doğru kararın verilmesi gerekir. Yatırımcılar bu kararı verirken, firmaya has olan veya olmayan farklı göstergeleri göz önünde tutmak durumundadır.

İşletmenin elde ettiği kârlılık, satışların artması, gelecekle ilgili beklentiler, yurt içi ve yurt dışı ekonomik ve sosyal gelişmeler yatırımcıların alım-satım kararları üzerinde etkili olabilmektedir. Bu faktörler de hisse senedinin arz ve talebine etki ederek piyasa fiyatını dolayısıyla hisse senedinin sağladığı getiriyi belirlemektedir. Hisse senetlerinin getirilerini belirleyen etkenler içsel ve dışsal faktörler olarak iki ana grupta incelenmektedir (Kanalıcı, 1997: 38-57).

Diğer taraftan içsel ve dışsal faktörlerle ilgili gelecek beklentileri de, firmanın bugünkü piyasa fiyatına önemli etki etmektedir. Bu nedenle hisse senedinin piyasa getirisini, sadece geçmiş ve bugünkü verilere göre değerlendirmemek gerekir. Henüz mali tablolara yansımamış farklı beklentiler, firmanın bugünkü durumu ile güncel hisse senedi getirisi ilişkisinin zayıflamasına neden olmaktadır.

Firmanın hisse senedinin getirisini etkileyen dışsal faktörler; enflasyon, faiz oranları, işsizlik, ekonomik büyüme, döviz kurları ve cari açık gibi değişik unsurlardan oluşmaktadır. Sayılgan ve Süslü (2011), Kanalıcı Akay ve Nargeleçekenler (2009), Ayaydın, H, Dağlı, H., (2012), Kaya, Çömlekçi ve Kara, (2013). Güngör ve Yerdelen Kaygın (2015) gibi çalışmalar farklı makroekonomik olayların hisse senedi getirilerini etkilediğini göstermektedir.

İçsel faktörler ise, firmanın faaliyet alanı, kapasitesi, pazar payı, satışları, kârlılığı ve bunun gibi unsurlardan oluşmaktadır. Lewellen (2004), Canbaş, Kandır ve Erişmiş (2008), Aydemir, Ögel ve Demirtaş (2012), Güngör ve Yerdelen Kaygın (2015).

Bir yatırımcı hisse senedi alım satımı kararını verirken teknik ve temel analiz gibi yöntemlerden faydalanabilmektedir. Teknik analiz hisse senedinin geçmiş fiyat/getiri, işlem hacmi gibi verilerinin analizi ile ilgilidir. Temel analiz ise; firmanın faaliyet yapısının, faaliyet sonuçlarının ve faaliyet beklentilerinin nitel ve nicel analizinden oluşmaktadır. Temel analiz yapan bir yatırımcı, karar verebilmek için gerekli analiz işlemine, öncelikle ülkenin genel ekonomik koşullarını ve konjonktürel yapısını inceleyerek başlamaktadır. Bunu sektör analizi ve firmanın analizi izlemektedir.

Ülkede işsizlik oranının artması, genellikle ekonomik yavaşlama ve durgunluk işareti olarak görülmekte ve firmaların gelirlerinin düşmesi beklenmektedir. Bu durum da firmanın borsa fiyatını ve getirisini düşüren bir etkiye neden olmaktadır. İşletmelerin faaliyet gösterdikleri sektörlerin farklılaşması, dışsal faktörlerin hisse senetlerinin fiyatları üzerindeki etkisinin farklılaşmasına neden olur. Bir ekonomik kriz, normal mal üreten firmaların satışlarını düşürürken, zorunlu gıda maddeleri üretimi yapan firmaların satışları ve kârlııkları ciddi olarak etkilenmeyebilir. Bu da sektör analizinin önemini yansıtmaktadır. Diğer bir önemli 
konu da firmanın kendi performansıdır. Satışlardaki veya kârlııktaki artış, firmaların hisse senetlerinin borsadaki getirisi üzerinde önemli bir etkiye sahip olabilmektedir.

Bazı durumlarda firmanın hisse senedine yatırım kararı sadece kâr veya sadece satış gibi değişkenlere dayanarak verilememektedir. Borsalarda kârlılı̆ı diğerlerine göre iyi firmaların hisse senetlerinin sağladığı getiri düşebilmekte, bazı durumlarda da zarar etmiş bir firmanın hisse senetleri daha iyi piyasa getirisi sağlayabilmektedir. Bu durumda, kârzarar verisi alım satım kararı için tek başına bir gösterge olamamaktadır. Ancak bazı durumlarda da bu hareketin nedeni, firmanın aldığı yeni bir yatırım kararı veya bir stratejik ortaklık sözleşmesi gibi gelecekte yüksek gelir getirme olasılığııı ortaya çıkmış olması olabilmektedir. Bazı zamanlarda da hisse senetlerinin getirileri üzerinde, manipülatif alımsatım işlemleri etkili olabilmekte, bu da hisse senedinin getirisi ile ekonomik gerçekler arasındaki bağın kopmasına neden olmaktadır.

Hisse senedi getirilerini, firmaların mali tablolarındaki birkaç değişkenle ilişkilendirmek yanlış olabilir. Bu durumda sadece satış veya kârlılık yerine, firmanın faaliyet performansını yansıtabilecek daha doğru bir ölçüye intiyaç duyulmaktadır. Az sayıda değişken yerine, firmanın durumu ile ilgili mali tablolardan elde edilebilecek daha fazla oran veya değer kullanılmalıdır. Bu da, çok sayıda değişken kullanılarak karar verme sorununu ortaya çıkarmaktadır.

Yatırımcıların çok sayıda değişken kullanılarak karar vermelerindeki sorunun çözümü için, literatürde yaygın olarak kullanılan çok değişkenli karar yöntemleri bir araç olabilmektedir. Analitik Hiyerarşi (AHS), ELECTRE, Gri llişkisel Analiz, Ekonomik Katma Değer (EVA), Piyasa Katma Değeri (MVA), Veri Zarflama Analizi (VZA), Malmquist Toplam Faktör Verimliliği Indeksi (TFV) ve TOPSIS gibi istatistiksel yöntemler, çok farklı alanlarda karar verebilmek için kullanılan yöntemlerdir. Bu çalışmada TOPSIS yöntemi çok sayıda finansal oran kullanılmasının yarattığı zorluğu ortadan kaldırmak için bir araç olarak seçilmiştir. TOPSIS yöntemi, firmaların finansal performanslarını ölçen bir yöntem olarak kullanılmaktadır. Buna örnek olarak Yükçü ve Atağan (2010), Demireli (2010), Dumanoğlu (2010), Soba, Akcanlı ve Erem (2012) gösterilebilir.

TOPSIS yöntemini kullanan Dumanoğlu (2010), Borsa İstanbul'da (BIST) işlem gören çimento sektöründeki 15 firmanın finansal performansını ölçmüştür. 2004-2009 dönemini ele alan çalışmada likidite, faaliyet ve kârlılık oranlarından oluşan 8 finansal oran kullanılmışır. Çalışma sonunda firmaların 6 yıllık dönem içinde her yıla ait performansları hesaplanmış ve her yıl hangi firmanın daha iyi performans sergilediği gösterilmiştir. Çalışmaya göre, 2004 yılında en iyi performansı Mardin Çimento gösterirken 2009 yılında Konya çimento en iyi performansı sergilemiştir. Ömürbek ve Mercan da (2014) imalat sektörünün 22 alt sektöründe yaptığı çalışma ile bu farklı sektörlerdeki firmaların finansal performanslarını 9 finansal oran ile TOPSIS ve ELECTRE yöntemlerini kullanarak kıyaslamayı amaçlamıştır. Çalışma sonunda "Kok kömürü ve rafine edilmiş petrol ürünleri imalatı" alt sektörü performansı en yüksek sektör olarak belirlenmiştir. Demireli (2010) de, TOPSis yöntemini Türkiye'deki kamu bankalarının performanslarını ölçmüştür. Yazar çalışmasındaki kamu bankaların performanslarında çalışma dönemi boyunca önemli bir olumlu gelişme 
yaşanmadığını göstermiştir. Yükçü ve Atağan (2010) da, firma performanslarını değerlemek amacıyla dört farklı oran yerine TOPSIS yöntemini kullanarak performans ölçütünü tek bir değere indirgemiştir. Bu sayede farklı illerde bulunan otellerin hangilerinin daha iyi performans gösterdiğini belirlemişlerdir. Ancak bu çalışmalar, firma performanslarıyla hisse senetlerinin piyasa fiyatları arasında ilişki aranan çalışmalardan değildir.

Soba, Akcanlı ve Erem (2012) çalışmalarında, taş ve toprağa dayalı sektörde faaliyet gösteren 26 işletme ile metal eşya makine ve gereç yapım sektöründe faaliyet gösteren 28 işletmenin 2008-2010 yılları arasındaki performans değerlendirmelerini TOPSIS yöntemlerini kullanarak yapmışlar ve sektörün en başarılı firmalarını sıralamışlardır.

Bu çalışmanın amacı, çok kriterli karar verme yöntemlerinden biri olan TOPSIS yöntemiyle şirketlerin finansal performanslarını belirlemek, ayrıca bu performans ve finansal oranlarla hisse senetlerinin borsa getirileri arasındaki ilişkiyi ölçmektir.

Bu amaçla, çalışmada öncelikle konuya yönelik olarak literatür taraması yer almış, bunu metodoloji takip etmiştir. Deneysel bulgular bölümünde, TOPSis yöntemiyle şirketlerin finansal performansları belirlenmiştir. Ayrıca performans ve finansal oranlarla hisse senetlerinin borsa getirileri arasındaki ilişkinin tespiti için korelasyon analizi uygulanmış ve elde edilen bulgular yorumlanmıştır. Çalışma, sonuçların değerlendirilmesi ile tamamlanmıştır.

\section{LITERATÜR ARAŞTIRMASI}

Hisse senetlerinin fiyat veya getirilerinin ortaya çıkmasında hangi unsurların ne derecede etkili olduğunun belirlenmesi yatırımcılar için önemli bir konudur. Bunun belirlenmesi, bireysel yatırımcıların çok sayıda işletme verisini doğru kullanmalarına yardımcı olacaktır. Literatür incelendiğinde hisse senedi getirilerini nelerin belirlediğini ortaya çıkarmayı hedefleyen çok sayıda akademik çalışmaya rastlanmaktadır.

Demir (2001), 1991 ve 2000 döneminde bankacılık sektöründe hisse senedi getirilerini açıklayan en önemli oranların, piyasa temelli oranlardan PD/DD ile F/K oranı ve kârlılık oranları (Hisse başına düşen kâr, Öz sermaye kârlılığı) olduğunu belirlemiştir.

Özer (1996), Borsa İstanbul'da (2012 yılından önceki ismiyle İstanbul menkul Kıymetler Borsası-IMKB) 1988-1992 döneminde günlük olarak işlem görmüş firmalardan 231'inin karları ile hisse senedi verimleri arasındaki ilişkileri incelemiş, firmaların açıkladığı kârların hisse senedi fiyatlarına, dolayısıyla getiriye yansıdığını belirlemiştir.

Kalaycı ve Karataş (2005), BisT imalat sektöründeki firmaların 1996 ve 1997 yıllarına ait 17 finansal oranı ile bu hisse senetlerinin getirileri arasındaki ilişkileri araştırmıştır. Yazarlar ilgili dönem için hisse senedi getirileri ile kârlılık oranları, borsa performans oranları ve verimlilik oranları arasında aynı yönlü ilişkiler elde etmişlerdir. 2000-2010 döneminde BisT'de yer alan 111 üretim firmasının finansal oranları ile piyasa getirileri arasındaki ilişkiyi araştıran Küçükkaplan (2013), piyasa değerindeki değişmenin \%23,3'lük kısmını finansal oranların açıkladığını bulmuştur. 
Karaca ve Baş̧̧ı (2011), Bíst 30 endeksinde aralıksız yer alan 14 firmanın 2001-2009 döneminde; net kâr marjı, esas faaliyet kâr marjı, varlıkların devir hızı ve özsermayenin devir hızı oranları ile hisse senedi getirisi arasında istatistiksel açıdan anlamlı ilişkiler elde etmişlerdir.

Bektaş ve Tekin (2013), kanonik korelasyon yöntemini kullanarak bankacılık sektöründe 2011 yılına ilişkin hisse senedi getirilerini açıklayan değişkenleri araştırmıştır. Çalışmaya göre, net aktif kârlılığı oranı ve PD/DD oranı getiriyi en iyi açıklayan iki değişken durumundadır.

Ayrıçay ve Türk (2014) ise, BiST üretim endeksinde yer alan 56 firmanın 2004-2011 dönemindeki finansal oranları ile piyasa getirileri arasındaki ilişkileri araştırmıştır. Panel veri analizi kullanılan çalışmanın bulgularına göre; asit test oranı, aktif devir hızı, PD/DD oranı ve finansal kaldıraç oranları anlamlı olarak etkin olduğu görülmüştür. Buna karşılık, borçlanma oranı ve bazı çalışmaların aksine aktif kârlılık oranı ile piyasa değeri arasında anlamlı ilişki bulunmamıştır.

Birgili ve Düzer (2010) çalışmalarında 2001-2006 dönemi için finansal oranlar ile firma değeri arasındaki ilişkiyi araştırmışlardır. Cari oran ve nakit oran, özkaynak/toplam aktif, toplam borç/ özkaynak, döner sermaye devir hızı, net kâr/özkaynak ve piyasa temelli oranlar ile (PD/DD, F/K) piyasa değeri arasında anlamlı ve pozitif bir ilişki elde edilmiştir. Toplam borç/toplam aktif, kısa vadeli borç/toplam borç oranlarının firmaların piyasa değeri ile ilişkisinin anlamlı ve negatif yönlü olduğu görülürken; aktif kârlılığı, net kâr / net satış oranı, aktif devir hızı, alacak devir hızı gibi oranlarla piyasa değeri arasında anlamlı bir ilişki bulunamamıştır. Kısa vadeli borç/ toplam borç oranı ile piyasa getiri arasında negatif, Uzun vadeli borç / toplam borç piyasa getirisi ilişkisinin anlamlı ve pozitif olması kısa dönem borç yükünün yatırımcıların alım-satım kararları üzerinde yarattığı farklı etkiyi ön plana çıkarmaktadır.

Uluyol ve Türk (2013), BiST’de işlem gören 56 üretim firmasının 2004-2010 dönemi için panel veri analizi kullanarak finansal oranların firma değerine etkisini araştırmıştır. Yazarlar, cari oran ve nakit oranın firma piyasa değerleri üzerinde anlamlı düzeyde etkili olduğunu bulurken, stok devir hızı, özsermaye oranı, net kâr marjı ve hisse başına düşen kâr oranları ile piyasa değerleri arasında bir ilişki bulunamamıştır.

Borsa İstanbul'da 1990-2009 döneminde imalat sanayi firmalarına ait 14 adet finansal oran ile hisse senedi getirileri arasındaki ilişkiyi panel veri yöntemi kullanarak inceleyen Aydemir, Ögel ve Demirtaş (2012), hisse senedi getirileri üzerinde kârlılık, likidite ve kaldıraç oranlarının pozitif etkiye sahip olduğunu, faaliyet oranlarının ise getirilerini etkilemediğini ortaya çıkarmıştır. Ancak çalışmada, bu finansal oranların hisse senedi getirilerini belirleme gücünün düşük olduğu belirlenmiştir.

Güngör ve Yerdelen Kaygın (2015), Borsa İstanbul'da 2005-2011 döneminde işlem gören ve süreklilik gösteren imalat sanayi işletmelerinin hisse senedi getirileri ile bazı mikro ve makro ekonomik faktörler arasındaki ilişkileri araştırmışlardır. Yazarlar çalışma sonunda, firmaya has bazı mikro faktörlerle getiri arasında anlamlı ilişki ortaya çıkarırken, bazı 
faktörler arasında ilişki elde edilmemiştir. Mikro faktörlerden cari oran, net kâr/toplam aktifler oranı, net kâr/net satışlar oranı, PD/DD oranı, temettü verimi bağımsız değişkenleri ile getiri arasında anlamlı ilişki olmadığı görülmüştür. Buna karşın asit test oranı, kısa vadeli yabancı kaynaklar/ toplam kaynaklara oranı, maddi duran varlıklar/öz kaynak oranı, net kâr/öz kaynak oranı ve fiyat/ kazanç oranı ile hisse senedi fiyatı arasında pozitif yönlü bir ilişki tespit edilmiştir. Alacak devir hızı ve stok devir hızı, toplam borçların/toplam aktiflere oranı ve kısa vadeli yabancı kaynaklar/ toplam kaynaklara oranı ile hisse senedi fiyatı arasında ise negatif yönlü ilişki elde edilmiştir. Yazarlar aynı dönemde, makroekonomik faktörlerden döviz kuru, para arzı, petrol fiyatları ve sanayi üretim endeksi ile hisse senedi fiyatı arasında pozitif yönlü bir ilişki bulurken; enflasyon oranı, faiz oranı, GSYiH, altın fiyatları ve dış ticaret dengesi ile getiri arasında ise negatif yönlü bir ilişki bulmuşlardır.

Canbaş, Kandır ve Erişmiş (2008) çalışmalarında yüksek defter değeri/piyasa değeri oranına sahip şirketlerin hisse senetleri, düşük defter değeri/piyasa değeri oranına sahip şirketlerin hisse senetlerine göre daha üstün performans sergilediğini, firma büyüklüğüne göre küçük firmaların hisse senetlerinin büyük firmaların hisse senetlerinden daha yüksek getiriler sağladığını belirlemiştir.

Yalçıner vd.(2005), 2000:12-2003:06 dönemi için Borsa İstanbul'da altışar aylık toplam 6 dönem finansal oran değerleri kullanarak, finansal oranlarda ortaya çıkan değişmelerin piyasa tarafından ne biçimde algılandığını ve hisse senedi fiyatlarına nasıl yansıdığını görmeyi amaçlamışlardır. Çalışmada VZA ve TFV analizleri kullanıımıştır. Yazarlar, 13 farklı finansal oranı girdi, 4 adet değişkeni ise çıktı değişken olarak kullanmışlardır. VZA ile etkin olduğu belirlenen firmalar ile hisse senetlerinin getirisi arasında yakın ilişki bulunmuştur. Ancak, TFV indeksi analizinde bir önceki döneme göre etkinliği artan firmaların hisse senetlerinin piyasa getirisinin de aynı düzeyde güçlü kanıt bulunamamıştır.

Sakarya ve Aytekin (2013), BIST'de 2007-2011 döneminde işlem gören bankaların finansal performanslarını PROMETHEE yöntemiyle belirledikten sonra, hesapladığı bu performans ölçüsü ile bankaların piyasa getirileri arasındaki ilişkiyi araştırmıştır. Yazar, analiz sonucunda finansal performans değerleri ile hisse senedi getirileri arasında gerek yıl bazında, gerekse de banka bazında istatistikî olarak anlamlı bir ilişkinin olmadığı sonucuna ulaşılmıştır.

Lewellen (2004), 1946-2000 yıllarını kapsayan çalışmasında Piyasa Değeri/Defter Değeri (PD/DD) oranı ve Fiyat/Kazanç (F/K) oranı gibi piyasa temelli oranlarla hisse senetleri arasında ilişki olduğunu belirlemiştir. Ancak F/K oranı kısa dönem getirilerini, PD/DD uzun dönem getirilerini etkilemektedir. Bunun yanında kâr payı verimi oranı da uzun dönem getirilerini açıklamaktadır.

Petcharabul ve Romprasert (2014), Tayland'da 1997-2011 dönemine ilişkin çeyrek dönem mali tablo verileri ile çalışarak Teknoloji sektöründe bulunan firmaların hisse senetlerinin faaliyet sonuçları ile hisse senedi borsa getirileri arasındaki ilişkileri ölçmüşlerdir. Yazarlar, Özsermaye karlılı̆ı ve PD/DD oranları ile hisse getirisi arasında önemli pozitif ilişki elde etmişlerdir. 
Kaya ve Öztürk (2015), firma kârlarının, hisse senedi yatırımcılarının yatırım kararlarını ve hisse senedini fiyatını etkileyen önemli bir faktör olduğunu ifade etmişlerdir. Bu nedenle çalışmalarında BIST Gıda, İçki ve Tütün Sektöründe faaliyet gösteren firmaların 2000-2013 yıllarında elde ettikleri muhasebe kârları ile hisse senedi fiyatları arasında ilişkiyi panel eşbütünleşme ve Granger nedensellik testi kullanılarak ele almışlardır. Analiz sonuçlarında muhasebe kârları ile hisse senedi fiyatlarının eşbütünleşik olduğu ve muhasebe kârlarını temsil eden aktif kârlılığı ve net kâr marjı değişkenlerinden hisse senedi fiyatı değişkenine doğru tek yönlü, esas faaliyet kârlılığı değişkeni ile hisse senedi fiyatı değişkeni arasında iki yönlü nedensellik tespit etmişlerdir.

Çalışmalar genel olarak değerlendirildiğinde; araştırmalarda kullanılan yöntem, dönem ve veri yapısı değiştikçe getiri ile getiriyi etkileyen faktörler arasındaki ilişkinin farklılaştığı görülmektedir. Örnek olarak çalışmanın birinde net aktif kârlılık oranı ile getiri arasında pozitif ve anlamlı bir ilişki bulunurken, bazı çalışmalarda bu ilişki ortadan kalkabilmektedir.

\section{VERI VE YÖNTEM}

\subsection{Amaç}

Çalışmanın amacı, şirketlerin finansal oranları yardımıyla finansal performanslarını tespit etmek ve bu finansal oranlar ve performanslar ile hisse getirileri arasındaki ilişkiyi ölçmektir. Fiyatın ortaya çıkmasında kârlııık, satışlar gibi içsel faktörler etkili olabildiği gibi, bunlardan sadece birisi bu ilişkiyi yansıtmaktan uzak kalabilmektedir. Bu nedenle firmaların mali yapısını mali tablolarından elde edilecek tek bir oran veya değer ile ifade etmek yerine, tüm bu oranlarının kullanımıyla çok değişkenli karar verme yöntemlerinden biri olan TOPSIS yöntemi kullanılarak hesaplanacak yeni bir değer ortaya konabilir. Elde edilen bu yeni değer, performans getiri ilişkisini belirlemede daha ön planda olabilir.

Çalışmada hisse senetlerinin borsa fiyatları baz alınarak oluşturulan hisse senedi getirileri ile öncelikle mali oranları arasındaki ilişkiler araştırılacaktır. Benzer biçimde firmanın borsa getirilerinin TOPSiS yöntemiyle elde edilen yeni değerlerle ilişkisi araştırılacaktır. Böylece yatırımcı çok sayıda mali orana bakarak karar vermek yerine, getiri ilişkisini yansıtan yeni bir gösterge kullanma olanağı elde edecektir.

Çalışmada, hisse senetleri Borsa İstanbul'da işlem gören gıda sektörü firmaları ele alınmıştır. Gıda sektörünün çalışma kapsamına alınmasının nedeni, insanların gıda tüketimlerinin kriz gibi ekonomik sorunlar karşısında diğer sektörlere göre daha düşük esneklik gösterdiğinin varsayılmasıdır. Çalışmada sektördeki tüm firmalar değil, bunlardan 4'ü seçilmiştir. Firmalardan ilki tavuk eti üretimi, ikincisi meyve suyu üretimi, üçüncüsü un üretimi ve sonuncusu da salça/konserve gibi alt gıda sanayisi dallarında faaliyet göstermektedir.

\subsection{Veri Yapısı}

Bu çalışmanın veri setini, Türkiye'de Gıda Sektöründe Faaliyet Gösteren ve Borsa İstanbul'da İşlem gören dört firmaya (Tablo 1) ait bilanço ve gelir tablolarından elde edilen finansal oranlar oluşturmaktadır. 
Tablo 1: Borsa İstanbul Gıda Endeksinde Yer Alan iş̧letmeler

\begin{tabular}{|l|l|}
\hline Borsa Kodu & işletme Adı \\
\hline BANVT & BANVIT BANDIRMA VITAMINLI YEM SANAYii A.Ş. \\
\hline ERSU & ERSU MEYVE VE GIDA SANAYI A.Ş. \\
\hline PETUN & PINAR ENTEGRE ET VE UN SANAYIi A.Ş. \\
\hline TATGD & TAT GIDA SANAYI A.Ş. \\
\hline
\end{tabular}

Çalışmada farklı düzeyde veriler elde edilerek analizi yapıımıştır. Analizde her bir firma için; 2000:4 ile 2014:3 dönemler arasında 56 çeyrek döneme ait 20 mali oran hesaplanmıştır. Hesaplanan mali oran sayısı bir firma için 1.120 olmak üzere, toplamda 4.480'dir. Kullanılan veriler Borsa İstanbul internet sayfası www.borsaistanbul.com.tr adresinden ve Kamuyu Aydınlatma Platformu internet sayfası www.kap.gov.tr adresinden elde edilmiştir.

Hisse senedi getirileri hesaplanırken, bilanço dönemi sonrasındaki üç aylık çeyrek döneme iliş̧in günlük kapanış fiyatlarının ortalaması alınmıştır. Böylece finansal oranların açıklanma tarihleri nedeniyle ortaya çıkan gecikme etkisi en aza indirilmek istenmiştir.

Finansal oranlar ve finansal performans ile getiri ilişkisini belirlemek için çalışmada, BiST Gıda sektörü tercih edilmiştir. Bunun nedeni, sektörün krizlerden az etkileneceğinin düşünülmesidir. Çünkü gıda, insanların en temel ihtiyacıdır. Innsanlar kriz zamanlarında bile gıda harcamalarını çok fazla kısamazlar. Sektörün krizlerden az etkilenecek olmasının, firmaların performanslarının borsa fiyatlarıyla karşılaştırılmasına diğer sektörlere göre daha elverişli olacağı düşünülmüştür.

Analizde 4 ana kategoride 20 adet finansal oran kullanılmıştır. Hisse senetlerinin piyasa getirilerinin, büyük oranda finansal oranlara yansıyacağı düşünülerek Piyasa temelli oranlar çalışma kapsamına alınmamıştır.

\subsection{Analiz Yöntemi}

Firmaların finansal performanslarını belirlemek için mali oranlara ilişkin veriler TOPSIS yöntemi kullanılarak analiz edilmiştir. TOPSIS analiz sonuçlarına göre 56 çeyrek için 4 ayrı şirket açııından birer performans değer serisi elde edilmiştir. Firmaların hisse senetlerinin borsa fiyatları ile TOPSIS yöntemine göre elde edilen performans değerleri arasındaki ilişki düzeyi Korelasyon analizi ile incelenmiştir.

TOPSIS (Technique for Order Preference by Similarity to Ideal Solution); çok kriterli karar verme tekniklerinden uygulanması kolay olan ve bulunan sonuçlar düzeyinde ise etkin ve verimli neticelere ulaştıran bir karar verme tekniğidir. Yöntem ise maksimum ve minimum değerler arasında karşılaştırma yapmaktadır. Bazı durumlarda ideal çözüm uygulanamaz ve ulaşılamaz sonuçlar doğurduğunda, ideale en yakın nokta belirlenmektedir (Soba vd. 2012:234).

1.ADIM: Karar Matrisi Oluşturmak

Karar matrisinde satırlara karar noktaları, sütunlara ise değerlendirme faktörleri yerleştirilir. Karar vericisinin oluşturmuş olduğu A matris başlangıç matrisidir (Sakthivel vd. 2015:244). 


$$
A_{i j}=\left[\begin{array}{cccc}
a_{11} & a_{12} & \ldots & a_{1 n} \\
a_{21} & a_{22} & \ldots & a_{2 n} \\
\cdot & & & \cdot \\
\cdot & & & \cdot \\
\cdot & & & \cdot \\
a_{m 1} & a_{m 2} & \ldots & a_{m n}
\end{array}\right]
$$

m: Karar noktası sayısı

$\mathrm{n}$ : Değerlendirme faktörü sayısı

\section{ADIM: Standart Karar Matrisinin Oluşturulması}

Karar matrisinde yer alan alternatifler $\left(a_{1} \ldots . . . a_{n}\right)$ şeklinde alt alta gelerek sıralanmakta ve her kriterin farklı alternatife göre biçimlenerek özellikler $\left(y_{1 k} \ldots . . . y_{n k}\right)$ şeklinde sıralanmaktadır (Demireli, 2010:105).

$$
r_{i j}=\frac{a_{i j}}{\sqrt{\sum_{k=1}^{m} a_{k j}^{2}}}
$$

i: $1 \ldots . . n$

J: $1 \ldots . . . k$

\section{ADIM: Ağırlıklı Standart Karar Matrisinin Oluşturulması}

İlk olarak değerlendirme faktörleriyle ilişkili olan ağırlık değerleri $\left(w_{i}\right)$ belirlenmektedir. Belirlenen ağırlık değerlerinin toplamı ise 1 olmalıdır (Alp ve Engin, 2011:69).

$\sum_{i=1}^{n} w_{i}=1$

Standart karar matrisinin $(R)$ her sütunda yer alan elemanlarının ağırlık değeri $\left(w_{\mathrm{i}}\right)$ ile çarpılıp ağırlıklı standart karar matrisi (V) meydana getirilir (Jadidi vd. 2008:764).

$$
V_{i j}=\left[\begin{array}{cccc}
w_{1} r_{11} & w_{2} r_{12} & \ldots & w_{n} r_{1 n} \\
w_{1} r_{21} & w_{2} r_{22} & \ldots & w_{n} r_{2 n} \\
\cdot & & & \cdot \\
\cdot & & & \cdot \\
\cdot & & & \cdot \\
w_{1} r_{m 1} & w_{2} r_{m 2} & \ldots & w_{n} r_{m n}
\end{array}\right]
$$


4.ADIM: İdeal ( $A^{*}$ ) ve Negatif İdeal ( $A^{-}$) Çözümlerin Oluşturulması

Karar matrisinin en iyi çözüm sonuçlarından oluşan ideal çözüm aralığı oluşmakla beraber en kötü çözüm skorlarıda kötü ve yetersiz değerlerden oluşmaktadır. Değer olarak ise maksimizasyon ya da minimizasyon yönlü olmasına göre değer ağırlıkları seçilir (Ustasüleyman, 2009:37).

$$
A^{*}=\left\{\left(\max _{i} v_{i j} \mid j \in J\right),\left(\min _{i} v_{i j} \mid j \in J^{\prime}\right\}\right.
$$

Negatif çözümde de aynı şekilde matristeki değer faktörleri minimizasyon ve maksimizasyon değerler olacak şekilde seçilir.

$$
A^{-}=\left\{\left(\min _{i} v_{i j} \mid j \in J\right),\left(\max _{i} v_{i j} \mid j \in J^{\prime}\right\}\right.
$$

5.ADIM: Ayırım Ölçülerinin Hesaplanması

Her karar noktası değerlendirmeleri için ideal çözümden olası sapmaları bulabilmek için uzaklık yaklaşımından yararlanılmaktadır. Sapma değerleri ideal ayrım $\left(\mathrm{S}_{i}^{+}\right)$ve negatif ideal ayrım ( $\mathrm{S}_{\mathrm{i}}^{-}$) ölçüsü şeklinde belirtilmektedir (Mahmoodzadeh vd., 2007:305).

$$
\begin{aligned}
& S_{i}^{*}=\sqrt{\sum_{j=1}^{n}\left(v_{i j}-v_{j}^{*}\right)^{2}} \\
& S_{i}^{-}=\sqrt{\sum_{j=1}^{n}\left(v_{i j}-v_{j}^{-}\right)^{2}}
\end{aligned}
$$

\section{ADIM: İdeal Çözüme Göreli Yakınlığın Hesaplanması}

Her bir değerin hesaplanmasının uygun çözümde doğrulamak için ideal ve negatif ayrım ölçülerinden faydalanılır. Bu ölçüt ise negatif ideal ayrım ölçüsünün toplamdaki ayrım ölçüsüne payıdır. Karar noktası ideal çözümü sonucu 1, negatif ideal çözüm sonucu 0 olarak ideal olan çözüme yakınlığı gösterir (Korkmaz, 2012:16).

$$
C_{i}^{*}=\frac{S_{i}^{-}}{S_{i}^{-}+S_{i}^{*}}
$$

\section{DENEYSEL BULGULAR}

Bu bölümde öncelikle çalışmaya konu olan işletmelerin ilgili dönemlerdeki TOPSIS skorları hesaplanarak bu işletmelerin finansal performansları tespit edilmeye çalışılmıştır. Daha 
sonra şirketlerin TOPSIS yöntemine göre belirlenen performansları, şirketlerin çalışmada baz alınan dönemler içerisindeki getirileri ile karşılaştıılarak aralarında herhangi bir korelasyon olup olmadığı belirlenmeye çalışılmıştır. Çalışmada son olarak şirketlerin baz alınan finansal oranları ile bu şirketlerin getirileri arasında korelasyon kurularak ilişki tespit edilmeye çalışılmıştır.

Çalışmada dikkate alınan dört işletmenin performansının belirlenmesinde TOPSIS yöntemi kullanılmış ve bunun için finans literatüründe çok kullanılan mali oranlardan yirmisi seçilmiştir. Çalışmada kullanılmak üzere seçilen yirmi (20) oran Tablo 2'de gösterilmiştir.

Tablo 2'de gösterilen mali oranlar dört işletme için ayrı ayrı hesaplanmıştır. Dönem olarak 2000 yılının son çeyreği ile 2014 yılının üçüncü çeyreği arası seçilmiş ve bu iki dönem arasındaki tüm çeyrek dönemlere ait olan Tablo 2'deki mali oranlar hesaplanmıştır.

Tablo 2: Analizde Kullanılan Yirmi (20) Finansal Oran

\begin{tabular}{|c|c|c|c|}
\hline ORANLAR & ORAN ADI & ORAN FORMÜLÜ & NO \\
\hline \multirow{3}{*}{$\begin{array}{l}\text { Likidite } \\
\text { Oranları }\end{array}$} & Cari Oran & Dönen Varlık / Kısa Vadeli Borç & 1 \\
\hline & Asit Test Oranı & (Dönen V.-Stoklar)/ Kısa Vadeli Borç & 2 \\
\hline & Nakit Oran & Hazır Değerler/KVB & 3 \\
\hline \multirow{6}{*}{$\begin{array}{l}\text { Mali Yapı } \\
\text { Oranları }\end{array}$} & Kaldıraç Oranı & $\begin{array}{l}\text { Toplam Yabancl Kaynaklar/Toplam } \\
\text { Pasif }\end{array}$ & 4 \\
\hline & Kısa Vadeli Yabancı Kaynak Oranı & Kısa Vadeli Borç /Toplam Pasif & 5 \\
\hline & Özkaynak Oranı & Özkaynaklar/Toplam Pasif & 6 \\
\hline & Duran Varlıklar/Özkaynaklar Oranı & Duran Varlıklar/Özkaynaklar & 7 \\
\hline & $\begin{array}{lll}\text { Duran } & \text { Varlıklar/Toplam } & \text { Aktifler } \\
\text { Oranı } & & \\
\end{array}$ & Duran Varlıklar/Toplam Aktifler & 8 \\
\hline & $\begin{array}{l}\text { Toplam Banka Krediler/Toplam } \\
\text { Aktifler Oranı }\end{array}$ & $\begin{array}{lll}\text { Toplam Banka } & \text { Kredileri/Toplam } \\
\text { Aktifler } & & \\
\end{array}$ & 9 \\
\hline \multirow{3}{*}{$\begin{array}{l}\text { Faaliyet } \\
\text { Oranları }\end{array}$} & Alacak Devir Hızı & Net Satışlar / Ort Ticari Alacaklar & 10 \\
\hline & Stok Devir Hızı & SMM/Ort. Ticari Mal Stoku & 11 \\
\hline & Aktif Devir Hızı & Net Satışlar/Toplam Aktif & 12 \\
\hline \multirow{8}{*}{$\begin{array}{l}\text { Kârlılık } \\
\text { Oranları }\end{array}$} & Net Kâr Marjı & Net Kâr / Net Satışlar & 13 \\
\hline & Öz Kaynak Kârlılık Oranı & Net Kâr / Öz Kaynak & 14 \\
\hline & Aktif Kârlılık Oranı & Net Kâr / Toplam Aktif & 15 \\
\hline & Ödenmiş Sermaye Kârlılık Oranı & Net Kâr/Ödenmiş Sermaye & 16 \\
\hline & Brüt Satış Kârı Oranı & Brüt Satış Kârı/Net Satışlar & 17 \\
\hline & Faaliyet Kârı Oranı & Faaliyet Kârı/Net Satışlar & 18 \\
\hline & Olağan Kâr Oranı & Olağan Kâr/Net Satışlar & 19 \\
\hline & Faaliyet Giderleri/Net Satışlar Oranı & Faaliyet Giderleri/Net Satışlar & 20 \\
\hline
\end{tabular}

$\mathrm{Bu}$ hesaplamaların sonucunda bulunan mali oran değerleri, TOPSIS skorlarının hesaplanmasında kullanılmış ve bulunan değerler aşağıdaki Tablo 3'te gösterilmiştir. 
Tablo 3: BiST’de İ̧lem Gören Dört Gıda Sektörü Firmasının TOPSıS Skorları

\begin{tabular}{|c|c|c|c|c|}
\hline Yıllar & BANVT & ERSU & PETUN & TAT \\
\hline $2000-4$ & 0,7343 & 0,2939 & 0,4136 & 0,3004 \\
\hline 2001-1 & 0,6094 & 0,2932 & 0,3210 & 0,3173 \\
\hline 2001-2 & 0,3892 & 0,3125 & 0,3167 & 0,3095 \\
\hline 2001-3 & 0,4012 & 0,3856 & 0,2466 & 0,2943 \\
\hline 2001-4 & 0,4211 & 0,3835 & 0,2593 & 0,3862 \\
\hline 2002-1 & 0,3947 & 0,3391 & 0,2840 & 0,4355 \\
\hline 2002-2 & 0,4647 & 0,3596 & 0,2676 & 0,4373 \\
\hline $2002-3$ & 0,5083 & 0,3964 & 0,2905 & 0,2996 \\
\hline $2002-4$ & 0,5132 & 0,4195 & 0,1606 & 0,6994 \\
\hline 2003-1 & 0,4740 & 0,3593 & 0,3035 & 0,3312 \\
\hline 2003-2 & 0,5295 & 0,3635 & 0,3256 & 0,2697 \\
\hline 2003-3 & 0,6189 & 0,3406 & 0,3369 & 0,2123 \\
\hline 2003-4 & 0,6488 & 0,3437 & 0,4355 & 0,2571 \\
\hline 2004-1 & 0,6311 & 0,3127 & 0,4163 & 0,2446 \\
\hline 2004-2 & 0,5784 & 0,2845 & 0,4083 & 0,2044 \\
\hline 2004-3 & 0,4997 & 0,2818 & 0,3929 & 0,1383 \\
\hline 2004-4 & 0,4896 & 0,3923 & 0,4107 & 0,2119 \\
\hline 2005-1 & 0,4867 & 0,2622 & 0,4535 & 0,1627 \\
\hline 2005-2 & 0,4622 & 0,3259 & 0,4461 & 0,1945 \\
\hline $2005-3$ & 0,4979 & 0,3289 & 0,4715 & 0,2500 \\
\hline 2005-4 & 0,5954 & 0,3555 & 0,4629 & 0,2293 \\
\hline 2006-1 & 0,4982 & 0,5136 & 0,5006 & 0,2203 \\
\hline 2006-2 & 0,4744 & 0,3084 & 0,4360 & 0,2726 \\
\hline 2006-3 & 0,4660 & 0,3854 & 0,5369 & 0,2652 \\
\hline 2006-4 & 0,5805 & 0,3953 & 0,6844 & 0,2010 \\
\hline 2007-1 & 0,4859 & 0,3674 & 0,6851 & 0,2738 \\
\hline $2007-2$ & 0,5607 & 0,3757 & 0,5386 & 0,2703 \\
\hline 2007-3 & 0,5858 & 0,4441 & 0,6953 & 0,3407 \\
\hline
\end{tabular}

\begin{tabular}{|c|c|c|c|c|}
\hline YIllar & BANVT & ERSU & PETUN & TAT \\
\hline $\mathbf{2 0 0 7 - 4}$ & 0,5549 & 0,6136 & 0,7541 & 0,2170 \\
\hline $\mathbf{2 0 0 8 - 1}$ & 0,5371 & 0,4014 & 0,5960 & 0,2550 \\
\hline $\mathbf{2 0 0 8 - 2}$ & 0,4961 & 0,3701 & 0,5427 & 0,2447 \\
\hline $\mathbf{2 0 0 8 - 3}$ & 0,4688 & 0,3612 & 0,5031 & 0,1730 \\
\hline $\mathbf{2 0 0 8 - 4}$ & 0,4046 & 0,3798 & 0,5664 & 0,1727 \\
\hline $\mathbf{2 0 0 9 - 1}$ & 0,3289 & 0,3464 & 0,6119 & 0,1832 \\
\hline $\mathbf{2 0 0 9 - 2}$ & 0,4080 & 0,3721 & 0,5710 & 0,2183 \\
\hline $\mathbf{2 0 0 9 - 3}$ & 0,4424 & 0,3913 & 0,5379 & 0,2010 \\
\hline $\mathbf{2 0 0 9 - 4}$ & 0,4559 & 0,3862 & 0,5446 & 0,2263 \\
\hline $\mathbf{2 0 1 0 - 1}$ & 0,4820 & 0,3983 & 0,6360 & 0,2742 \\
\hline $\mathbf{2 0 1 0 - 2}$ & 0,4874 & 0,3981 & 0,5663 & 0,2971 \\
\hline $\mathbf{2 0 1 0 - 3}$ & 0,4919 & 0,3927 & 0,5185 & 0,2555 \\
\hline $\mathbf{2 0 1 0 - 4}$ & 0,4921 & 0,4210 & 0,5421 & 0,2663 \\
\hline $\mathbf{2 0 1 1 - 1}$ & 0,4687 & 0,4079 & 0,7232 & 0,2791 \\
\hline $\mathbf{2 0 1 1 - 2}$ & 0,4569 & 0,3953 & 0,5621 & 0,2875 \\
\hline $\mathbf{2 0 1 1 - 3}$ & 0,4052 & 0,3806 & 0,5007 & 0,2620 \\
\hline $\mathbf{2 0 1 1 - 4}$ & 0,4423 & 0,3976 & 0,5141 & 0,3008 \\
\hline $\mathbf{2 0 1 2 - 1}$ & 0,4711 & 0,3784 & 0,5873 & 0,2852 \\
\hline $\mathbf{2 0 1 2 - 2}$ & 0,4568 & 0,3974 & 0,4934 & 0,2784 \\
\hline $\mathbf{2 0 1 2 - 3}$ & 0,4775 & 0,3882 & 0,5236 & 0,2287 \\
\hline $\mathbf{2 0 1 2 - 4}$ & 0,4139 & 0,3732 & 0,5217 & 0,2414 \\
\hline $\mathbf{2 0 1 3 - 1}$ & 0,3871 & 0,4153 & 0,5947 & 0,2816 \\
\hline $\mathbf{2 0 1 3 - 2}$ & 0,3793 & 0,3901 & 0,5660 & 0,2693 \\
\hline $\mathbf{2 0 1 3 - 3}$ & 0,2942 & 0,3590 & 0,6130 & 0,2334 \\
\hline $\mathbf{2 0 1 3 - 4}$ & 0,3152 & 0,3803 & 0,5977 & 0,2751 \\
\hline $\mathbf{2 0 1 4 - 1}$ & 0,3809 & 0,3701 & 0,5066 & 0,2637 \\
\hline $\mathbf{2 0 1 4 - 2}$ & 0,3420 & 0,4136 & 0,5029 & 0,2553 \\
\hline $\mathbf{2 0 1 4 - 3}$ & 0,3930 & 0,3927 & 0,5383 & 0,3075 \\
\hline
\end{tabular}

Tablo3'te yer alan değerlerin tespiti için ağırlıklı normalize edilmiş karar matrisinde ağırlıklandırma işleminde tüm kriterlerin aynı önem derecesinde olduğu kabul edilmiş ve 20 kriterin ağırlıkları toplamının 1 değerine eşit olması gerektiğinden her bir kriter 0.05 ağırlık değeri ile çarpılmıştır. TOPSIS yönteminin uygulanması sonucunda elde edilen değerler Tablo 3'te yer almakla birlikte, bu değerler çalışmada dikkate alınan dört 
işletmenin finansal performanslarını göstermektedir. Tablo 3'te birçok değerin yer alması nedeniyle hangi işletmenin daha yüksek bir performansa sahip olduğunun anlaşılması zor görülmektedir. Bu nedenle bu veriler bir grafiğe dökülerek tekrar aşağıdaki Şekil 1'de gösterilmeye çalışılmıştır.

\section{Şekil 1: BiST’de İ̧̧lem Gören Dört Gıda Sektörü Firmasının TOPSIS Skorları}

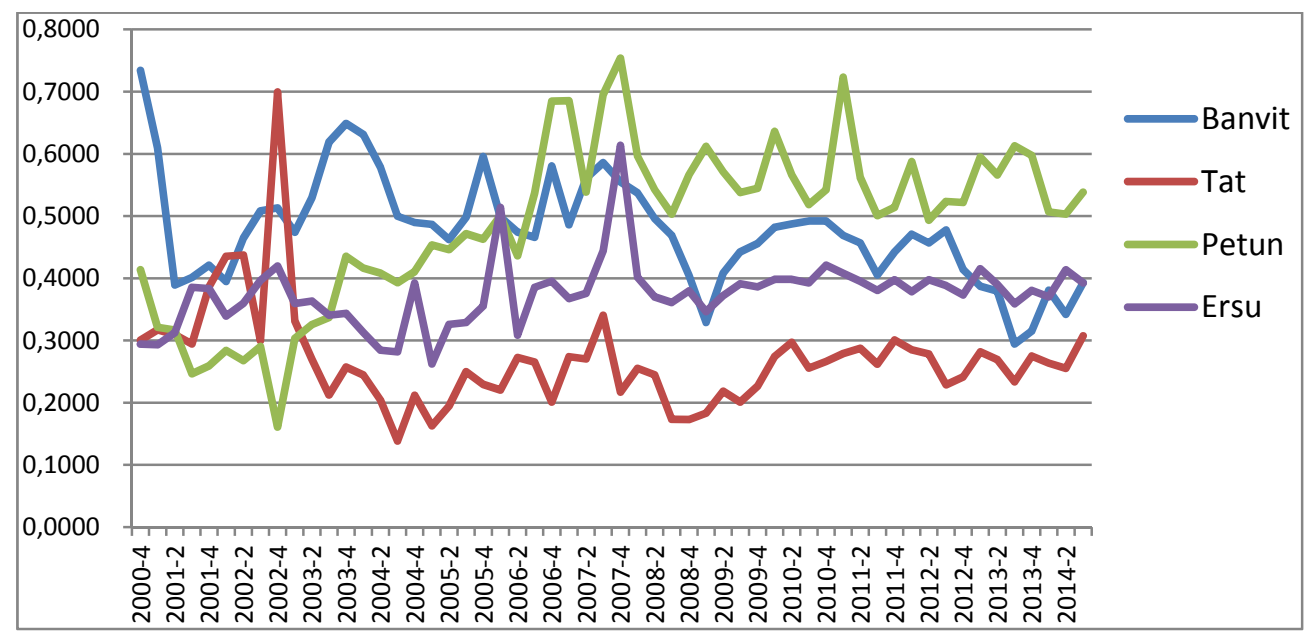

Şekil 1'de yer alan, BiST'de işlem gören dört gıda sektörü firmasının TOPSIS Skorları incelendiğinde, yıllar itibariyle en yüksek performansa sahip olan işletmenin, ilk dönemler hariç, genellikle Pınar Entegre Et ve Un Sanayii A.Ş. (PETUN) olduğu görülmektedir. Şekilden de görüleceği gibi, 2006 yılından itibaren PETUN skorlarının 0,50'nin, 2007 ve 2011 yıllarında bu oranın 0,70'in üzerindedir. Bu işletmeyi, baz alınan dönemlerin başında en yüksek performansa sahip olan ancak bu performansı bu dört işletme arasında son yıllarda azalışa geçen Banvit Bandırma Vitaminli Yem Sanayii A.Ş (BANVT) takip etmektedir. Bu işletmenin TOPSIS skorları 2004 yılından itibaren bir trend çizerek 0,60 seviyelerinden 0,30 seviyelerine kadar düşmüştür. 2000 ile 2014 yılları arasında dört işletme arasında genellikle üçüncü olarak performans gösteren işletmenin ise Ersu Meyve ve Gıda Sanayi A.Ş. (ERSU) olduğu dikkat çekmektedir. ERSU işletmesi 2007 yılında 0,60 seviyelerine kadar yükselse de, bu işletmenin TOPSIS skorlarının genellikle 0,30 ile 0,40 arasında yatay seyrettiği görülmektedir. Son olarak ilk dönemler hariç olmak üzere, dört işletme arasında en düşük performansa sahip olan işletmenin ise Tat Gıda Sanayi A.Ş. (TATGD) olduğu Şekil 1'de çok rahat bir şekilde görülmektedir. TATGD işletmesinin TOPSIS skorlarının ilk dönemler hariç 0,20 ile 0,30 arasında yatay seyrettiği söylenebilir.

TOPSIS yöntemiyle elde edilen skorların finansal performans göstergesi olarak anlamlılığının test edilmesi gerekir. Bunun için getiriler dikkate alınabilir. Gıda sektörü işletmelerinin (4 işletme) 2000-2014 yılları arasındaki üç aylık ortalama getirileri ile bu işletmelere ilişkin elde edilen TOPSIS skorları arasındaki korelasyon düzeyleri aşağıdaki Tablo.4'te gösterilmiştir. 
Tablo 4'e göre, BANVT'in getirileri ile TOPSIS skorları arasındaki korelasyon 0,229, ERSU'nun getirileri ile TOPSIS skorları arasındaki korelasyon 0,152, PETUN'un getirileri ile TOPSIS skorları arasındaki korelasyon 0,126 ve TATGD'nin getirileri ile TOPSIS skorları arasındaki korelasyon $-0,077^{\prime}$ dir. Tablo.4'te yer alan sonuçlarda görüleceği gibi, genel itibariyle değişkenler arasındaki korelasyon 0,25 düzeyinin altında kalmıştır. Bu durum, bu iki değişken arasındaki ilişkinin çok zayıf olduğunu gösterir. Ayrıca TATGD’nin getirileri ile TOPSIS skorları arasında güçlü olmasa da ters yönlü bir ilişkinin olduğu anlaşılmaktadır. Dolayısıyla bu sonuçlara göre TOPSIS yönteminden elde edilen verilerle değerlendirme yapmak çok sağlıklı olmayacağı söylenebilir.

Tablo 4: Hisse Senedi Getirileri ile TOPSIS Skorları Arasındaki Korelasyon Düzeyi

\begin{tabular}{|c|c|c|c|c|c|}
\hline & & $\begin{array}{l}\text { BANVT } \\
\text { TOPSIS }\end{array}$ & $\begin{array}{c}\text { ERSU } \\
\text { TOPSIS }\end{array}$ & $\begin{array}{l}\text { PETUN } \\
\text { TOPSIS }\end{array}$ & $\begin{array}{l}\text { TATGD } \\
\text { TOPSIS }\end{array}$ \\
\hline \multirow[t]{2}{*}{ BANVT GETIRI } & Pearson Correlation & ,229 & & & \\
\hline & Sig. (2-tailed) & 090 & & & \\
\hline \multirow[t]{2}{*}{ ERSU GETIRI } & Pearson Correlation & & 152 & & \\
\hline & Sig. (2-tailed) & & 263 & & \\
\hline \multirow[t]{2}{*}{ PETUN GETIRI } & Pearson Correlation & & & ,126 & \\
\hline & Sig. (2-tailed) & & & ,354 & \\
\hline \multirow[t]{2}{*}{ TATGD GETIRI } & Pearson Correlation & & & &,- 077 \\
\hline & Sig. (2-tailed) & & & &, 572 \\
\hline \multicolumn{6}{|c|}{ **. Korelasyon 0,01 düzeyinde anlamlıdır (2-tailed). } \\
\hline \multicolumn{6}{|c|}{ *. Korelasyon 0,05 düzeyinde anlamlıdır (2-tailed). } \\
\hline \multicolumn{6}{|l|}{$N=56$} \\
\hline
\end{tabular}

Çalışmada ikinci bir uygulama yapılmıştır. Çalışmada ikinci bir uygulama yapılmasının amacı; getiri ile TOPSIS performans ölçüsü arasında bulunamayan korelasyonun, finansal oranların tek tek dikkate alınarak, bulunup bulunmayacağının tespitidir. Buna yönelik veriler Tablo.5'te gösterilmiştir.

Üç aylık ortalama finansal oranlar ile üç aylık ortalama hisse senedi getirileri arasında istatistiki olarak anlamlı bir ilişki olup olmadığını belirlemek için dönemler bazında korelasyon testi uygulanmış ve sonuçlar Tablo.5'te gösterilmiştir. Tablo.5 genel olarak incelendiğinde, yapılan Korelasyon testleri sonucunda çok az değişken arasında korelasyon olduğu dolayısıyla da anlamlı olan ilişkilerin çok az olduğu anlaşılmaktadır.

Tablo.5'te tespit edilebilen önemli diğer bir sonuç ise, mali oranlar ile hisse getirileri arasında çok az korelasyon olmasının yanında, korelasyonların 0,50'nin altında kalmış olması nedeniyle, bu korelasyonların güçlü olmadığıdır. Tablo 5’e göre, hisse senedi getirileri ile korelasyonun olduğu finansal oran değişkenlerinin genellikle Kârlılık Oranları olduğu görülmektedir. Getirisiyle oranları arasında en çok korelasyon olan hisse senedinin ise BANVT olduğu anlaşılmaktadır. Hisse getirileriyle oranlar arasında hiçbir korelasyona sahip olmayan tek işletme ise ERSU olmuştur. Dikkat çeken diğer bir unsur ise, BANVT hissesi doğru orantılı korelasyonlar içermektedir. Buna karşın TATGD ile PETUN hisseleri çok az korelasyona sahip olmakla beraber bu korelasyonların tümü negatif orantılıdır. Ancak aralarındaki korelasyon kuvvetli değildir. 
Tablo 5: Hisselerin Getirileriyle Finansal Oranlar Arasındaki Korelasyon Düzeyi

\begin{tabular}{|c|c|c|c|c|c|}
\hline & & $\begin{array}{l}\text { BANVT } \\
\text { GETIRI }\end{array}$ & $\begin{array}{l}\text { ERSU } \\
\text { GETIRI }\end{array}$ & $\begin{array}{l}\text { PETUN } \\
\text { GETIRI }\end{array}$ & $\begin{array}{l}\text { TATGD } \\
\text { GETIRI }\end{array}$ \\
\hline \multirow[t]{2}{*}{ Cari Oran } & Pearson Correlation & ,222 & ,100 & ,025 &,- 145 \\
\hline & Sig. (2-tailed) & ,100 & ,462 & ,856 &, 285 \\
\hline \multirow{2}{*}{ Asit Test Oranı } & Pearson Correlation & ,201 &, 060 & ,052 &,- 073 \\
\hline & Sig. (2-tailed) & ,138 &, 660 & ,705 &, 591 \\
\hline \multirow{2}{*}{ Nakit Oran } & Pearson Correlation &,- 081 & ,108 & 095 &,- 036 \\
\hline & Sig. (2-tailed) &, 554 & 429 & ,485 & ,791 \\
\hline \multirow{2}{*}{ Kaldıraç Oranı } & Pearson Correlation &,- 156 &,- 034 &,- 127 & ,094 \\
\hline & Sig. (2-tailed) & ,252 & ,806 & ,351 & ,493 \\
\hline \multirow{2}{*}{$\begin{array}{l}\text { Kısa Vadeli Yabancı } \\
\text { Kaynak Oranı }\end{array}$} & Pearson Correlation &,- 128 &,- 018 &,- 142 & 012 \\
\hline & Sig. (2-tailed) & ,347 & ,898 & ,296 & ,929 \\
\hline \multirow{2}{*}{ Özkaynak Oranı } & Pearson Correlation &, $276^{*}$ & 022 & ,140 &,- 102 \\
\hline & Sig. (2-tailed) &, 040 & , 870 & ,302 &, 454 \\
\hline \multirow{2}{*}{$\begin{array}{l}\text { Duran } \\
\text { Varlıklar/Özkaynaklar } \\
\text { Oranı }\end{array}$} & Pearson Correlation &,- 215 & , 042 &,- 070 & ,173 \\
\hline & Sig. (2-tailed) & 111 & ,759 & 608 & ,202 \\
\hline \multirow{2}{*}{$\begin{array}{l}\text { Duran } \\
\text { Varlıklar/Toplam } \\
\text { Aktif }\end{array}$} & Pearson Correlation &,- 035 &, 038 & ,143 & ,262 \\
\hline & Sig. (2-tailed) & ,799 & ,778 & ,295 & ,051 \\
\hline \multirow{2}{*}{$\begin{array}{l}\text { Banka Krediler / } \\
\text { Toplam Aktif }\end{array}$} & Pearson Correlation &,- 016 &,- 135 &,- 190 & , 184 \\
\hline & Sig. (2-tailed) & ,909 & ,320 & ,161 & ,174 \\
\hline \multirow{2}{*}{ Alacak Devir Hızı } & Pearson Correlation &,- 168 &,- 029 &,- 002 & ,158 \\
\hline & Sig. (2-tailed) & ,216 &, 832 & ,991 & ,244 \\
\hline \multirow{2}{*}{ Stok Devir Hızı } & Pearson Correlation & ,156 & 141 &,- 077 & ,223 \\
\hline & Sig. (2-tailed) &, 252 & ,299 &, 574 & ,099 \\
\hline \multirow{2}{*}{ Aktif Devir Hızı } & Pearson Correlation &, $319^{*}$ & ,123 & ,023 & ,094 \\
\hline & Sig. (2-tailed) &, 016 & ,365 & 869 & 489 \\
\hline \multirow{2}{*}{ Net Kâr Marjı } & Pearson Correlation &, $473^{* *}$ &, 064 & ,193 &,- 193 \\
\hline & Sig. (2-tailed) &, 000 & 638 & ,153 & ,154 \\
\hline \multirow{2}{*}{$\begin{array}{lll}\text { Net Öz Kaynak } \\
\text { Kârlılık Oranı }\end{array}$} & Pearson Correlation &, $380^{* *}$ & ,032 & ,198 &,- 137 \\
\hline & Sig. (2-tailed) &, 004 & 816 & ,143 & ,314 \\
\hline \multirow{2}{*}{$\begin{array}{l}\text { Net Aktif Kârlılık } \\
\text { Oranı }\end{array}$} & Pearson Correlation &, $457^{* *}$ & ,068 & ,184 &,- 182 \\
\hline & Sig. (2-tailed) &, 000 & ,620 & ,175 & ,180 \\
\hline \multirow{2}{*}{$\begin{array}{lr}\text { Net } & \text { Ödenmiş } \\
\text { Sermaye } & \text { Kârlılık } \\
\text { Oranı } & \\
\end{array}$} & Pearson Correlation &, $436^{* *}$ & 101 & 191 &,- 200 \\
\hline & Sig. (2-tailed) & ,001 & ,457 & 159 & 139 \\
\hline \multirow{2}{*}{$\begin{array}{l}\text { Brüt Satış Kârlılığı } \\
\text { Oranı }\end{array}$} & Pearson Correlation & ,134 & 121 &,- 139 &,$- 267^{*}$ \\
\hline & Sig. (2-tailed) & ,326 & ,374 & ,307 & ,047 \\
\hline \multirow{2}{*}{$\begin{array}{ll}\text { Faaliyet Kârlılığı } \\
\text { Oranı }\end{array}$} & Pearson Correlation &, $296^{*}$ & ,096 &,- 022 &,$- 264^{*}$ \\
\hline & Sig. (2-tailed) &, 027 & ,483 & ,871 &, 049 \\
\hline \multirow{2}{*}{ Olağan Kâr Oranı } & Pearson Correlation &, $474^{* *}$ & ,057 & ,154 &,- 244 \\
\hline & Sig. (2-tailed) &, 000 & 678 & ,258 & ,070 \\
\hline \multirow{2}{*}{$\begin{array}{l}\text { Faaliyet } \\
\text { Giderleri/Net } \\
\text { Satışlar Oranı }\end{array}$} & Pearson Correlation &,- 247 &,- 009 &,$- 318^{*}$ &,- 037 \\
\hline & Sig. (2-tailed) &, 066 & ,946 & ,017 & ,788 \\
\hline
\end{tabular}




\section{SONUÇ}

İ̧̧letmelerin piyasa fiyatlarını belirleyen çok sayıda içsel ve dışsal etken bulunmaktadır. Bu çalışma esas olarak işletme içi etkenlerden finansal oranlarla, işletmelerin piyasa getirisi arasındaki ilişkiyi ortaya çıkarmayı amaçlamaktadır. Çalışmadaki işletmelerin hisse senetlerinin piyasa getirileri ile finansal oranları arasında, tek tek ilişki araştırılmıştır. Bununla birlikte, birçok kriterin bulunduğu durumlarda karar vermeyi sağlayan araçlardan biri olan TOPSIS yöntemi ile işletmelerin her çeyrekteki performansı hesaplanmıştır. Hesaplanan bu performans skorları ile hisse senedi getirileri arasındaki ilişki araştırılmıştır.

Çalışmada BIST gıda endeksinde yer alan seçilmiş 4 işletmenin 2000:4 ile 2014:3 arasındaki 56 çeyrek dönemlerindeki finansal performansları TOPSIS yöntemi ile ölçülmüştür. TOPSIS yöntemi ile hesaplanan skorlarla hisse senedi getirileri arasında yapılan korelasyon analizi sonucunda, hesaplanan performans skorları ile hisse senedi getirileri arasında 4 işletme için de istatistiksel olarak anlamlı bir ilişki bulunamamıştır. Böylece yatırımcılar, incelenen dönem için TOPSIS yöntemi ile bulunan skorlara göre hisse senedi alım satım kararı vermekten uzaktır. Bu durumda yatırımcılar, mali tabloların tümü üzerindeki değişmelere karşı duyarsız kalmışlardır.

Oranlar düzeyinde yapılan korelasyon analizine göre; finansal oran ile getiri arasında az sayıda istatistiksel olarak anlamlı ilişki bulunmuştur. Çalışma kapsamındaki işletmelerden ERSU işletmesinin finansal oranları ile getirileri arasında istatistiksel olarak anlamlı olan hiçbir ilişki bulunmamıştır. PETUN işletmesi için sadece Faaliyet Giderleri/Net satışlar oranı, getiri ile anlamlı ancak negatif bir korelasyon ilişkisine sahiptir. TATGD işletmesine ait oranlarla getirileri arasında Brüt Satış Kârlılığı Oranı ve Faaliyet Kârlılığı Oranı arasında anlamlı ancak negatif bir ilişkiye rastlanmıştır. Bu üç işletmenin piyasa getirileri neredeyse tamamen finansal tablo verilerinden bağımsız olarak ortaya çıkmıştır. Yatırımcılar bu işletmelerin, finansal tablo ve finansal oranlarındaki gelişmelere karşı duyarsız kalmış oldukları söylenebilir.

Finansal oranlarla getiri arasında en çok ilişkinin bulunduğu işletme BANVT'tir. Bu işletmenin piyasa getirileri ile Özkaynak oranı, Aktif devir hızı, Net kâr marjı, Özkaynak kârlılığı, Net aktif kârlılığı, Net Ödenmiş sermaye kârlıığı, Faaliyet Kârlılığı ve Olağan Kâr oranı arasında anlamlı ve pozitif ilişkiler bulunmuştur. Bu durumda üç işletmenin fiyat oluşumunda içsel faktörler piyasada fiyatlanmazken, diğerlerine göre çok daha büyük boyutlu olan BANVT işletmesinde getiriler, büyük çoğunlukla kârlılık oranları tarafından belirlenmektedir.

Bu durum borsada fiyat oluşum mekanizmalarının işleyişi hakkında da bir fikir vermektedir. 2014-12 mali tablolarına göre diğer her üç işletmenin (ERSU, PETUN ve TATGD) aktifleri BANVT işletmesinin aktifinin sırası ile \%4, \%45 ve \%67'si kadardır. BANVT işletmesinin net satışlara göre kıyaslama yapıldığında, ERSU \%1, PETUN \%28,4 ve TATGD \%42,2 düzeyindedir. Buna göre genel olarak bakıldığında işletmelerin hisse senetlerinin getirileri içsel faktörlerin etkisini yansıtmamaktadır. İşletmelerin küçük olması, dışsal faktörlerin etkisini ön plana çıkarmıştır. 
Diğerlerine göre daha büyük ölçekli bir işletme olan BANVT işletmesi için ortaya çıkan sonucun literatürdeki çoğu çalışmayla benzerlik gösterdiği görülmektedir. Özer (1996), Demir (2001), Kalaycı ve Karataş (2005), Karaca ve Başçı (2011), Bektaş ve Tekin (2013), Güngör ve Yerdelen Kargın (2015)'nın çalışmalarında da başta kârııık oranları olmak üzere finansal oranlar ile getiri arasında anlamlı ilişkiler bulunmuştur. Bu durumda, BiST yatırımcısının bazı işletmeler için işlem kararı verirken kârlıı̆ı ön sıraya koyduğunu söylemek mümkündür.

Diğer 3 işletme için ortaya çıkan sonuç; Uluyol ve Türk (2013), Sakarya ve Aytekin (2013), Aydemir, vd. (2012) ve Güngör vd. (2015) gibi çalışmalarla uyumludur. Aydemir, vd. (2012), finansal oranların hisse senedi getirilerini belirleme gücünün düşük olduğu belirlemiştir. Güngör vd. (2015)'nin çalışmasında pek çok kârılık oranı ile getiri arasında ilişki bulunamamış, dışsal faktörlerin getiri üzerinde önemli etkisi ortaya koyulmuştur. Bu da yatıımcıların bazı hisse senetlerini satın alırken, daha çok işletme dışı faktörleri dikkate aldıkları hissini uyandırmaktadır.

Bu çalışmanın dikkat çekici sonuçlarından biri de, bu çalışmanın yanı sıra Sakarya ve Aytekin (2013)'in çalışmasında da olduğu gibi çok değişkenli karar verme yöntemlerine göre bulunan performans ölçülerinin hisse getirileri üzerinde etkili olmamasıdır. Buna göre; yatırımcıların karar verirken işletmelerin genel başarı göstergelerine göre değil, başta kârlılık olmak üzere sınırlı sayıda gösterge kullandıkları söylenebilir.

TOPSIS yönteminin finansal performans göstergesi olma özelliği ile ilgili olarak Saldanlı ve Sırma (2014), yaptıkları çalışmada; TOPSIS yöntemini BIST-100 imalat sanayi işletmelerinin verilerine ve BIST bankacılık endeksindeki banka verilerine uygulamıştır. Yazarlar, TOPSIS skorlarını yaptıkları iki uygulamada da hisse senedi getirileri arasında istenilen $+0,50$ düzeyinde bir ilişki gözlememişlerdir. Bu durumda yöntemin yatırımcılara, yapacakları yatıım kararlarında yardımcı olma özelliği olmadığı sonucuna varmışlardır. Sakarya ve Aytekin (2013)'ün PROMETHEE yöntemini kullandığı çalışmasında da bulunan skorların getiriyi yansıtmamış olması, bu tür çok kriterli karar verme tekniklerinin finansal veriler için kullanıma uygun olup olmadığı konusunun da sorgulanmasını gündeme getirmektedir.

\section{KAYNAKÇA}

Alp, S. ve Engin, T. (2011). Trafik Kazalarının Nedenleri ve Sonuçları Arasındaki İlişkinin TOPSIS ve AHP Yöntemleri Kullanılarak Analizi ve Değerlendirilmesi. İstanbul Ticaret Üniversitesi Fen Bilimleri Dergisi, 10(19), Bahar, 65-87.

Ayaydın, H. ve Dağlı, H. (2012). Gelişen Piyasalarda Hisse Senedi Getirisini Etkileyen Makroekonomik Değişkenler Üzerine Bir İnceleme: Panel Veri Analizi, Atatürk Üniversitesi Iktisadi ve Idari Bilimler Dergisi, 26(3-4), 45-65.

Aydemir, O. Ögel, S. ve Demirtaş, G. (2012). Hisse Senetlerinin Fiyatlarının Belirlenmesinde Finansal Oranların Rolü, Yönetim ve Ekonomi, 19(2), 277-288.

Ayrıçay, Y. ve Türk, V.E. (2014). Finansal Oranlar ve Firma Değeri iliş̧kisi: BisT’de Bir Uygulama. Muhasebe ve Finansman Dergisi, 16(64), 53-70.

Bektaş, H. ve Tekin, M. (2013). Finansal Oranlar ve Borsa Performans Oranları illişkisi: IMKB'de İşlem Gören Bankaların Kanonik Korelasyon Analizi, Marmara Üniversitesi iiBF Dergisi, XXXIV(I), 317-329.

Birgili, E. ve Düzer, M. (2010). Finansal Analizde Kullanılan Oranlar ve Firma Değeri illişkisi: IMKB'de Bir Uygulama, Muhasebe ve Finansman Dergisi, 46, 74-83. 
Borsa İstanbul İnternet Sayfası, www.borsaistanbul.com

Canbaş, S. Kandır, S.Y. ve Erişmiş, A. (2008). IMKB Şirketlerinde Büyüklük ve Defter Değeri/Piyasa Değeri Oranının Hisse Senedi Getirilerine Etkisinin Analizi, IMKB Dergisi, 10(39), 1-18.

Demir, Y. (2001). Hisse Senedi Fiyatını Etkileyen İşletme Düzeyindeki Faktörler ve Mali Sektör Üzerine IMKB'de Bir Uygulama, Süleyman Demirel Üniversitesi Iktisadi ve Idari Bilimler Fakültesi Dergisi, 6(2), 109-130.

Demireli, E. (2010). TOPSIS Çok Kriterli Karar Verme Sistemi: Türkiye'deki Kamu Bankaları Üzerine Bir Uygulama, Girişimcilik ve Kalkınma Dergisi, 5(1), 101-112.

Dumanoğlu, S. (2010). IMKB'de İşlem Gören Çimento Şirketlerinin Mali Performansının TOPSis Yöntemi ile Değerlendirilmesi. Marmara Üniversitesi iiBF Dergisi, XXIX(II), 323-339.

Güngör, B. ve Yerdelen Kaygın, C. (2015). Dinamik Panel Veri Analizi İle Hisse Senedi Fiyatını Etkileyen Faktörlerin Belirlenmesi, Kafkas üniversitesi, iktisadi ve Idari Bilimler Fakültesi, KAU IiBF Dergisi, 6(9), 149-168.

Jadidi, O. Hang, T.S. Firouzi, F. Yusuff, R.M. ve Zulkifli, N. (2008). TOPSIS and Fuzzy Multi-Objective Model Integration for Supplier Selection Problem, Journal of Achievements in Materials and Manufacturing Engineering, 31, 762-769.

Kalaycı, Ş. ve Karataş, A.(2005). Hisse Senedi Getirileri ve Finansal Oranlar İlişkisi: İMKB'de Bir Temel Analiz Araştırması, Muhasebe ve Finans Dergisi, 27, 146-157.

Kamuyu Aydınlatma Platformu İnternet sayfası, www.kap.gov.tr

Kanalıcı, H. (1997). Hisse Senedi Fiyatlarının Tesbiti ve Tesir Eden Faktörler. Sermaye Piyasası Kurulu, Yayın No: 77, Ankara.

Kanalıcı Akay, H. Nargeleçekenler, M. (2009). Anadolu Uluslar arası İktisat Kongresi, 17-19 Haziran, Eskişehir.

Karaca, S.S. Başçı E.S. (2011). Hisse Senedi Performansını Etkileyen Rasyolar ve IMKB 30 Endeksinde 2001-2009 Dönemi Panel Veri Analizi, Süleyman Demirel Üniversitesi, iktisadi ve Idari Bilimler Fakültesi Dergisi, 16(3), 337347.

Kaya, A. ve Öztürk, M. (2015). Muhasebe Karları İle Hisse Senedi Fiyatları Arasındaki i̇lişki: BiST Firmaları Üzerine Bir Uygulama, Muhasebe ve Finansman Dergisi, 67, 37-54.

Kaya, V. Çömlekçi, İ. ve Kara, O. (2013). Hisse Senedi Getirilerini Etkileyen Makroekonomik Değişkenler 20022012 Türkiye Örneği, Dumlupınar Üniversitesi Sosyal Bilimler Dergisi, 35, 167-176.

Korkmaz, M. (2012). Orman İşletmelerinde İktisadilik Düzeyinin TOPSıS Yöntemi ile Analizi. SDÜ Orman Fakültesi Dergisi / SDU Faculty of Forestry Journals, 14-20.

Küçükkaplan, İ. (2013). İstanbul Menkul Kıymetler Borsasında İşlem Gören Üretim Firmalarının Piyasa Değerini Açıklayan İçsel Değişkenler: Panel Verilerle Sektörel Bir Analiz. Eskişehir Osmangazi Üniversitesi iiBF Dergisi, Ekim, 8(2), 161-182.

Lewellen, J. (2004). Predicting Returns with Financial Ratios, Journal of Financial Economics, 74, $209-235$.

Mahmoodzadeh, S. Shahrabi, J. Pariazar, M. ve Zaeri, M.S. (2007). Project Selection by Using Fuzzy AHP and TOPSIS Technique, International Journal of Social, Education, Economics and Management Engineering, 1(6), 301-306.

Ömürbek, N. ve Mercan, Y. (2014). İmalat Alt Sektörlerinin Finansal Performanslarının Topsis ve Electre Yöntemleri İle Değerlendirilmesi. Çankırı Karatekin Üniversitesi Iktisadi ve İari Bilimler Fakültesi Dergisi, 4(1), 237-266.

Özer, G. (1996). Muhasebe Kârları ile Hisse Senedi Verimleri Arasındaki İlişkiler iMKB'de Deneysel Bir analiz. Sermaye Piyasası Kurulu Yayın No: 31, Ankara.

Petcharabul, P. ve Romprasert, S., (2014), Technology Industry on Financial Ratios and Stock Returns, Journal of Business and Economics, ISSN 2155-7950, USA, DOI: 10.15341/jbe(2155-7950)/05.05.2014/012, May 2014, 5(5), 739-746 
Sakarya, Ş. ve Aytekin. S. (2013). IMKB'de Iş̧lem Gören Mevduat Bankalarının Performansları ile Hisse Senedi Getirileri Arasındaki Iliş̧inin Ölçülmesi: PROMETHEE Çok Kriterli Karar Verme Yöntemiyle Bir Uygulama. Uluslararası Alanya Iş̧letme Fakültesi Dergisi, 5(2), 99-109.

Sakthivel, G. Ilangkumaran, M. ve Gaikwad, A. (2015). A hybrid Multi-Criteria Decision Modeling Approach for the Best Biodiesel Blend Selection Based on ANP-TOPSIS Analysis, Ain Shams Engineering Journal, 6(1), 239-256. doi:10.1016/j.asej.2014.08.003

Saldanlı, A. ve Sırma, i. (2014). TOPSIS Yönteminin Finansal Performans Göstergesi Olarak Kullanılabilirliği, Marmara Üniversitesi Öneri Dergisi, 11(41), 185-202.

Sayılgan, G. ve Süslü, C. (2011). Makroekonomik Faktörlerin Hisse Senedi Getirilerine Etkisi: Türkiye ve Gelişmekte Olan Piyasalar Üzerine Bir İnceleme, BDDK Bankacılık ve Finansal Piyasalar, 5(1), 73-96.

Soba, M. Akcanlı, F. ve Erem, I. (2012). iMKB'ye Kayıtlı Seçilmiş İ̧̧letmelere Yönelik Etkinlik Ölçümü ve Performans Değerlendirmesi: Veri Zarflama Analizi ve TOPSis Uygulaması. Selçuk Üniversitesi Sosyal Bilimler Enstitüsü Dergisi, $27,229-243$.

Uluyol, O. ve Türk, V.E. (2013). Finansal Rasyoların Firma Değerine Etkisi: Borsa İstanbul (BiST)'da Bir Uygulama. Afyon Kocatepe Üniversitesi IiBF Dergisi, XV( II), 365-384.

Ustasüleyman, T. (2009). Bankacılık Sektöründe Hizmet Kalitesinin Değerlendirilmesi: AHS-TOPSIS Yöntemi, Bankacılar Dergisi, 69, 33-43.

Yalçıner, K. Atan, M. ve Boztosun, D. (2005). Finansal Oranlarla Hisse Senedi Getirileri Arasındaki Ilişki. Muhasebe ve Finansman Dergisi, 27, 176-187.

Yükçü, S. Atağan, G. (2010). TOPSis Yöntemine Göre Performans Değerleme, Muhasebe ve Finansman Dergisi, 45, 28-3. 